Egyptian Journal of Aquatic Biology \& Fisheries

Zoology Department, Faculty of Science,

Ain Shams University, Cairo, Egypt.

ISSN 1110 - 6131 Vol. 22(5): 401- 404 (2018)

ejabf.journals.ekb.eg

\title{
Record and distribution of puffer fish, Takifugu oblongus (Bloch, 1786) (Actinopterygii: Tetraodontidnae) from Tapi River, Gujarat.
}

\section{Thakkar Nevya ${ }^{1}$, Sarma Kangkan Jyoti ${ }^{1}$, Tatu Ketan ${ }^{2}$, Kamboj Ravi D. ${ }^{2}$ and Mankodi Pradeep ${ }^{1 *}$}

1- Division of Freshwater and Marine Biology, Department of Zoology, Faculty of Science, The Maharaja Sayajirao Univ. Baroda, Vadodara - 390002, Gujarat, India.

2- Gujarat Ecological Education and Research (GEER) Foundation, Indroda Nature Park, Sector - 7, Gandhinagar - 382007, Gujarat, India.

*Corresponding author: pcmankodi@yahoo.com

\section{ARTICLE INFO}

Article History:

Received: July, 24, 2018

Accepted: Dec. 15, 2018

Online: Dec. 28, 2018

Keywords

Puffer fish

Tetraodontidae

Distribution

Tapi River

Gujarat.

\section{ABSTRACT}

Takifugu oblongus (Bloch, 1786) (Actinopterygii: Tetraodontidae), is a puffer fish found in shallow coastal waters has a native distribution in entire Indo-West Pacific region (Froese and Pauly, 2014). This species is observed in shallow coastal ecosystems such as estuaries, mangroves, coral reefs and sand and gravel sediments, including the soft bottom areas of inshore and offshore regions. Takifugu oblongus is one of the widely distributed species among the genus Takigufu but no report or publication has been made so far from the western coast of India. This paper reports the record of the fish from Magdalla along the course of Tapi River, Surat, Gujarat.

\section{INTRODUCTION}

Puffer fishes are oval shaped and possess spines all around their bodies with toxic glands beneath. They have the ability to inflate or expand their bodies with air or water when they feel threatened and are most commonly found in marine or brackish water habitats (Nelson, 1994; Shipp, 2003). This species is observed in shallow coastal ecosystems such as estuaries, mangroves, coral reefs and sand and gravel sediments, including the soft bottom areas of inshore and offshore regions. It invades areas from the shallow regions to deeper regions, with depths in the range of 10-100 m (Leis, 1984; Froese and Pauly, 2014). The family Tetraodontidae consists of 189 species in 28 genera (Oliveira et al., 2006) comprising of one of the largest families of puffer fishes. The identification of the Tetraodontiformes is very difficult owing to their same characteristics nature and their biological study is still in the preliminary stages. Distributional data record at Southeast coast of India (Veeruraj, 2011) and toxicological profile at Bay of Bengal (Indumathi and Khora, 2017; Ghosh, 2004), and studies of heavy metal content and proximate analysis on puffer fishes (Karunanidhi, 2017) and from Gujarat studies has been conducted on marine carnivore feeding on Takifugu oblongus(Gadhavi et al., 2013). 
The, Lattice blaasop, Takifugu oblongus (Bloch, 1786) belongs to the family of Tetraodontinae (puffers) and has a wide distribution in the Indo and Western Pacific Ocean extending from South Africa to Indonesia, to the north to Japan and also south of Australia. The present study details the first record and description of Takifugu oblongusfrom Tapi River, Gujarat.

\section{MATERIALS AND METHODS}

Takifugu oblongus (Bloch, 1786), commonly called as puffer fish, a species belonging to the family Tetraodontinae was caught and recorded from Tapi River for the first time $\left(21^{\circ} 08^{\prime} 43.42^{\prime \prime} \mathrm{N}\right.$ and $72^{\circ} 44^{\prime} 51.14$ 'E) on 04.11 .2017 . Three samples were collected from a fisherman during regular surveys using a cast net of $10 \mathrm{~mm}$ from a place name Magdalla (Fig. 1), in Surat district which is situated at an elevation of 15 metres from the sea.

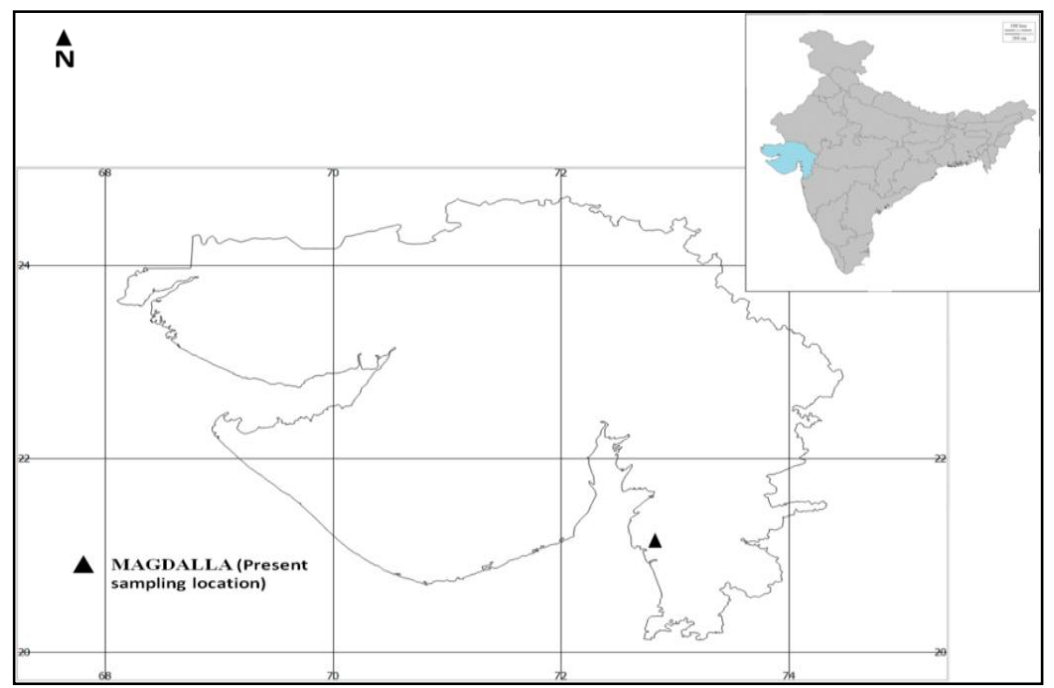

Fig 1. Map showing the area of catch of theTakifugu oblongus(Bloch, 1786)

The morphological and meristic characters of the specimen were recorded using Vernier Calliper and the identification of the species was confirmed using standard available keys like Day's Volume I and II (Day, 1888), Fishes of the World (Nelson, 1994) and also was verified using FAO and Leibniz Institute of Marine Science in Kiel, Germany managed website www.fishbase.org, a global species database of fishes (Froese and Pauly, 2017). On site photographic documentation was done for the specimen to record the actual colour and body patterns. The specimen has been well preserved in $10 \%$ formalin and deposited in the museum of division of Freshwater and Marine Biology, Department of Zoology, Faculty of Science, The Maharaja Sayajirao University of Baroda, Vadodara with the voucher number ZL$\mathrm{CH}-\mathrm{OSH}-027$ for future reference.

\section{RESULTS}

The characters of the specimen are very identical with the general description of the species. Consisting of a cylindrical body, small and oval eyes head gently arched towards the short caudal peduncle, straight abdomen, maximum body width at the pectoral fins, it is having brownish in colour above with yellowish white below and narrow dark bars on sides. The small and terminal mouth is thick lipped, 
protruding upper jaw, beak like teeth on the both the jaws. Nostrils are plate-like with two openings. The pelvic fins are absent and caudal fin is truncated. Like most of the puffer fishes, small spinucles are present from nares to insertion of dorsal fin beginning from the lower jaw to the anus and also around the base of pectoral fin. Three darker transverse bands are present between pectoral fins and at dorsal fin base. White bands of irregular shape extend from lateral midline toward dorsum. The pectoral and caudal fins are yellowish in colour.

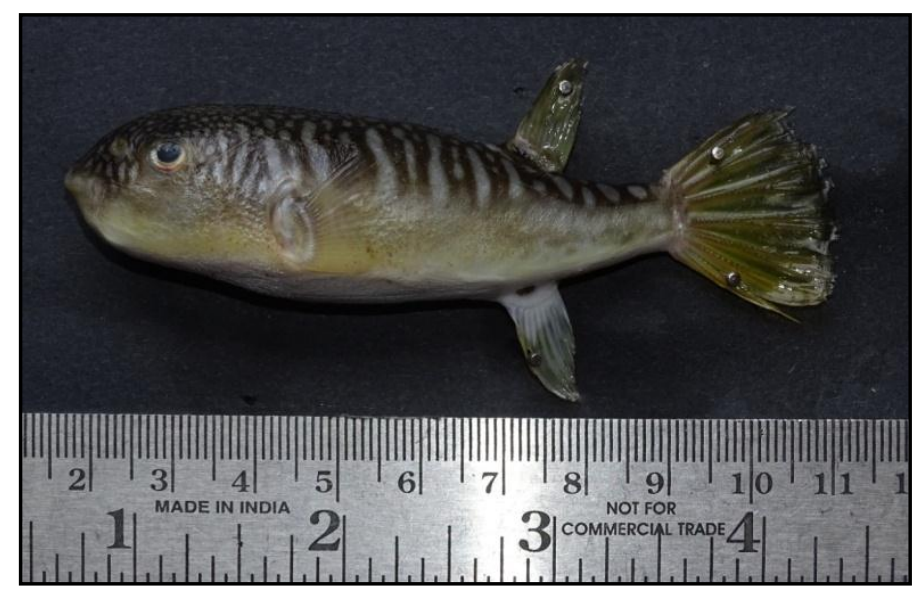

Fig. 2: Takifugu oblongus, $105 \mathrm{~mm}$ total length, caught from Tapi River, Gujarat

The morphological features of the studied specimen (Fig. 2) are as follows: Dorsal fin rays (D) - 12, Anal fin rays -10 , Caudal fin rays -09 , Pectoral fin rays 12, Total length (TL) - $105 \mathrm{~mm}$, Standard length (SL) - $85 \mathrm{~mm}$, Head length (HL) 25mm, Snout length (SNL) - $10 \mathrm{~mm}$, Head width (HW) $-20 \mathrm{~mm}$, Pectoral fin length (PFL) $-8 \mathrm{~mm}$. SL was $80.95 \%$ of TL, HL was $29.40 \%$ of SL, SNL was $11.76 \%$ of SL, PFL was $9.41 \%$ of SL and $32 \%$ of HL, HW was $23.53 \%$ of SL and $80 \%$ of HL.

\section{DISCUSSION}

In the present study, Takifugu oblonguswas recorded from estuarine waters of Tapi River and its occurrence has been reported form the freshwater or tidal influenced zone of Gujarat for first time indicating a significant range extension of previously known distribution like Eastern and Southeast coast in the Indian subcontinent. Takifugu oblongus is one of the widely distributed species among the genus Takigufubut no report or publication has been made so far from the western coast of India. This species is exclusively a marine fish but the current distribution of the species in Magdalla, $7 \mathrm{kms}$ inside from the mouth of Tapi River can be extrapolated to the fact of less outflow of fresh water in the rivers because of less rainfall and construction of artificial weirs or dams and larger inflow of brackish waters into the rivers might have brought on such a kind of distribution. It is very early to consider whether only extra limited individuals exploring a new area represent the present catch or whether there is a well-established population which might have remain undetected due to lack of ichthyological surveys and fishery expeditions. Further work is very much essential to determine the frequency of occurrence of the species and also to establish characteristics in order to resolve whether it has established a sustainable population in its new surroundings. 


\section{Acknowledgments}

The authors are grateful to the Gujarat Ecological Education and Research (GEER) Foundation, Gandhinagar, Gujarat for the research grant with sanction letter number GCU-2/GEER-48/16-17/1132 dated 18/03/2017 entitled "Survey work in the field of Ichthyofauna". The authors are also thankful to the Head, Department of Zoology for the laboratory, storage and museum facilities. Mr. Parth Prajapati and Mr. Dhaval Bhatt are acknowledged for their fieldwork assistance.

\section{Declaration of interest}

There is no actual or potentialconflict of interestincluding any financial, personal or other relationships with other people or organizations.

\section{REFERENCES}

Anguchamy Veeruraj, M.A.; Ajithkumar, T., and Balasubramanian, T. (2011). Distribution of Tetraodontiformes (Family: Tetraodontidae) along the Parangipettai Coast, Southeast coast of India. Zootaxa, 3015, 1 - 12.

Day, F. (1888). The fishes of India: being a natural history of the fishes known to inhabit the seas and fresh waters of India, Burma, and Ceylon (Vol. 1).

Froese, R.A. and Pauly, D. (2009). Fishbase: A global information system on fishes. International Center for Living Aquatic Resources Management. http://www.fishbase.org.

Gadhvi. M.K.; Kardani, H.K. and Pathak, R. (2013). Observations on the marine carnivore gastropods feeding on moribund Puffer Fish Takifugu oblongus (Bloch 1786). Zoo's Print, Volume XXVIII, Number 6.

Ghosh, S.; Hazra, A.K.; Banerjee, S. and Mukherjee, B. (2004). The seasonal toxicological profile of four puffer fish species collected along Bengal coast, India. Indian Journal of Marine Sciences, 33 (3): 276 - 280.

Indumathi, S. M. and Khora, S. S. (2017). Toxicity assessment and screening of tetrodotoxin in the Oblong blowfish (Takifugu oblongus) from the Tamil Nadu Coast of Bay of Bengal, India. Asian Pac. J. of Trop. Med., 10(3): 278 - 284.

Karunanidhi, K., Rajendran, R., Pandurangan, D., and Arumugam, G. (2017). First report on distribution of heavy metals and proximate analysis in marine edible puffer fishes collected from Gulf of Mannar Marine Biosphere Reserve, South India. Toxicol. Reports, 4, 319-327.

Leis, (1984). Tetraodontiformes: Relationships. Ontogeny and systematics of fishes, $459-463$.

Nelson, (1994). Fishes of the world 3rd edn. John Wiley and Sons Inc. Newyork, USA, ISBN, 831014144, 234pp.

Oliveira, J.S.; Fernandes, S.C.R.; Schwartz, C.A.; Bloch Jr, C.; Melo, J.A.T.; Pires Jr, O.R., and De Freitas, J.C. (2006). Toxicity and toxin identification in Colomesus asellus, an Amazonian (Brazil) freshwater puffer fish. Toxicon, 48(1): $55-63$.

Shipp, (2003). Tetraodontidae. In Carpenter K.E. (ed) FAO species identification guide for fishery purposes. The living marine resources of the Western Central Atlantic. Vol. 3: 1988 - 2006. Rome, Italy: FAO of the United Nations. 